Received: June, 2019

Accepted: December, 2019

ISSN $2006-6996$

\title{
ANTIBIOTIC RESISTANCE PATTERNS OF Campylobacter jejuni and Salmonella Typhi ISOLATED FROM READY-TO-EAT VEGETABLE SALADS HAWKED IN KANO METROPOLIS
}

\author{
Mohammed, $B^{*}$. and Muhammad, A. U.
}

Department of Microbiology, Faculty of Life Sciences, Bayero University, Kano

Corresponding author: bshchemiron@yahoo.com; 07012789177

\begin{abstract}
A total of 200 samples of Ready - to - Eat (RTE) vegetable salads were aseptically purchased randomly from hawkers in eight Local Governments of Kano State, Nigeria. The Aerobic mesophilic bacterial count was conducted according to standard techniques. Samples were further screened for S. Typhi and C. jejuni using standard procedures. Isolates of the two bacterial species were subjected to antibiotic sensitivity testing using Kirby Buer disk diffusion technique. The total aerobic bacteria count ranged from 1.200 $\times 10^{5}$ to $1.70 \times 10^{5} \mathrm{cfu} / \mathrm{g}$. A total of 36 bacterial isolates from the RTE vegetables were identified as C. jejuni (18\%) and $97(48.5 \%)$ as S. Typhi. Ninety percent (90\%) of the bacterial isolates were found to be resistant to the assayed antibiotics. $C$. jejuni was highly sensitive (98.4\%) to gentamicin. TEM genes were detected in $40 \%$ of the C. jejuni isolates while 60\% were detected in S. Typhi isolates. RTE vegetable salads hawked in the study areas are contaminated with C. jejuni and S. Typhi and the isolates were resistant to most of the antibiotics tested. It is recommended that hazard analysis and critical control point of ready to eat food should be observed.

Keywords: Vegetable salads, Aerobic mesophilic bacterial counts, C. jejuni and S. Typhi, Kirby-Baeur disc diffusion technique
\end{abstract}

\section{INTRODUCTION}

Salad is a mixture of fresh vegetables (tomatoes, cucumber, carrots, onions, cabbage, and lettuce etc.) that provides a rich source of vitamins, minerals and dietary fiber of low fat and calories to the consumer ( Abdul-Raouf and Ammar, 2011; Adeshina et al., 2012; Udo et al., 2008; Itohan et al., 2011). In recent years, salad has become a very popular component of menu served at birthday and wedding parties; they are also sold in fast food centers in most major cities in Nigeria. The consumption rates of vegetables and vegetable salads have also greatly increased based on their proven medical and nutritional benefits (Udo et al., 2009; Adeshina et al., 2012; Puspanadan et al., 2012). Recently, vegetables are sliced and beautifully arranged in layers in transparent plastic containers and hawked in almost every market, motor parks and other public places. Media reports of unverified rampant cases of gastroenteritis following consumption of meals served with fresh vegetable salads have become serious public health concern (Udo et al., 2008).

Salad has high water content because of its dressing but it is low in calories and hence, it is used by people who are aiming at weight loss, help in disorders and strokes.

Moreover, the availability of potable water for proper washing of these vegetables is also lacking in different areas. As a result of which dirty or contaminated water is used for washing which could lead to further increasing the microbial load on these vegetables which some people buy and eat without further washing and also it can become contaminated with pathogenic microorganisms during harvesting, through human handling, harvesting equipments and transport containers (Hassan et al., 2006; Elexson et al., 2017; New et al., 2017).

Campylobacter jejuni and Salmonella Typhi have been implicated in many food borne disease outbreaks related to fresh produce (Beuchat, 2002; Maffei et al., 2013) making them potential threat to consumers. Several outbreaks of human gastro-enteritis have been linked to the consumption of contaminated fresh vegetable salad (Udo et al., 2008). Among the well-related food borne pathogens are; Esherichia coli 0157 (Shiga toxin E. coll), Listeria monocytogenes, Salmonella sp., Vibrio sp., Yersinia sp., and Campylobacter sp. (Jong, 2010). 
BAJOPAS Volume 12 Number 2, December, 2019

Antimicrobial resistance is a growing public health threat and has been designated by the World Health Organization as an emerging public health problem (Komolafe, 2003). The problem arises when bacteria causing disease withstand therapy. Thus, the issue on biosafety with regard to antibiotic resistance must be addressed at a global level (Chai et al., 2008). The prevalence of antimicrobial resistance among pathogens from vegetables has increased during the recent decade in developed countries (Holvoet et al., 2013). However, reports of the antibiotic sensitivity of these bacteria are only presently emerging in developing countries. Transmission of antimicrobial resistant bacteria is a potential concern with unhygienic handling of vegetables (Adesetan et al., 2013).

In view of the growing concerns on the bacteriological safety of the salads sold in Kano, growing resistance of bacteria to antibiotics and increase in consumption of the salads by the teeming populace, there was need for the study on the antibiotic resistance pattern of $\mathrm{C}$. jejuni and $\mathrm{S}$. Typhi isolated from ready to eat vegetable salads hawked in Kano Metropolis..

\section{MATERIALS AND METHODS \\ Study area}

The Kano urban area covers $137 \mathrm{sq} . \mathrm{km}$ and comprises eight Local Government Areas; Kano Municipal Council (KMC), Dala (DAL), Gwale (GWL), Fagge (FGE), Ungoggo (UGG), Kumbotso (KBT), Nassarawa (NSR) and Tarauni (TRN).

\section{Sampling Sites}

The samplings were market places, motor parks and roadsides in all the eight (8) local government areas.

\section{Sample size}

Sample size was calculated using the formula; $\mathrm{n}=\mathrm{Z}^{2} \mathrm{PQ} / \mathrm{d}^{2}$

Where $\mathrm{n}$ - number of samples $=$ ?

Z- Normal distribution $=1.960$

P- Prevalence obtained from previous research $=5.56 \%$ and $11 \%$.

$$
\begin{aligned}
& \text { Q- } 1-P= \\
& d-0.05 \\
& n=200
\end{aligned}
$$

\section{Sample collection and Processing}

Two hundred vegetable salads (25 from each local government) were purchased randomly from different hawkers at markets, motor parks, schools as well as road sides in a sterile aluminium foil paper. The samples were immediately taken to Postgraduate Laboratory at the Department of Biological Sciences, Bayero University Kano in an ice box for analyses.

Fresh and apparently healthy vegetables (cabbage, lettuce, cucumber, onions and tomatoes) were purchased from Rimi Market in Kano Municipal Council Local Government and washed with clean water. Using sterile knife and chopping board, the vegetables were cut and mixed together and analysed in the laboratory for bacteriological contamination (Partially Treated Control).

Fresh and apparently healthy vegetables (cabbage, lettuce, cucumber, onions and tomatoes) were purchased from Rimi Market and washed with clean water. Water and distilled white vinegar were poured in a clean bowl at ratio $3: 1$, the vegetables were soaked inside the bowl for 3 minutes and rinsed under clean running water according to the Manufacturer's instructions. Using sterile knife and chopping board, the vegetables were cut and mixed together. This was used for bacteriological analyses (Treated Control).

\section{Enumeration Bacteria}

This was carried out by serial dilution and pour plating (Egboh and Emeshili, 2007). Twenty five gram (25g) of the homogenized sample was transferred into a conical flask containing $225 \mathrm{ml}$ of buffered peptone water (BPW) using sterile pipette syringe and labeled $10^{-1}$ (stock solution). One millilitre from tube $10^{-1}$ was transferred after agitation into another test tube containing $9 \mathrm{ml}$ of BPW (using a separate syringe) and labeled $10^{-2}$, this was repeated to obtain $10^{-3}$, $10^{-4}$ and $10^{-5}$. Using another fresh syringe, $1 \mathrm{ml}$ of sample from each dilution was transferred into two sterile petridishes and labeled accordingly. This was followed by pouring nutrient agar in each petridish, swirled clockwise and anti-clockwise and allowed to solidify. Finally the plates were incubated at $37^{\circ} \mathrm{C}$ for 24 hours. Colonies that developed were thereafter counted and expressed as colony forming unit per gramme (CFU/g).

\section{Detection of Campylobacter jejuni}

The selective media used to isolate Campylobacter jejuni was charcaol cefoperazone desoxycholate agar (CCDA; Oxoid, Basingstoke, UK). Then, $22.75 \mathrm{~g}$ of the media was suspended in $500 \mathrm{ml}$ of distilled water and brought to boil to dissolve. The media was sterilized by autoclaving at $121^{\circ} \mathrm{C}$ for 15 minutes and cooled to $50^{\circ} \mathrm{C}$. One vial of CCDA selective supplement SR0155 was aseptically added and reconstituted as directed. It was mixed well and poured into sterile petridishes containing $1 \mathrm{ml}$ of homogenised vegetable sample. Plates were anaerobically incubated at $37^{\circ} \mathrm{C}$ for 48 hours. Plates were observed for colonial and morphological appearance. 
BAJOPAS Volume 12 Number 2, December, 2019

\section{Detection of Salmonella Typhi}

Salmonella-Shigella agar was used to isolate Salmonella Typhi. The media was prepared by suspending $31.5 \mathrm{~g}$ of SS agar into $500 \mathrm{ml}$ of distilled water. The media was heated to boiling with frequent agitation to dissolves completely not autoclaved or overheated because overheating may destroy the selectivity of medium. The media was cooled to about $50^{\circ} \mathrm{C}$. The media were mixed well and poured into sterile Petri dishes containing $1 \mathrm{ml}$ of homogenised vegetable sample. Plates were incubated at $37^{\circ} \mathrm{C}$ for 24 hours. This was further confirmed with gram staining and biochemical test as described by Cheesbrough (2006).

\section{Gram Staining}

All the isolates were subjected Gram staining according to the standard method as described by Cheesbrough (2006).

\section{Biochemical test for characterization of} bacteria

Bacterial isolates were characterized using biochemical tests (catalase, oxidase, indole, urease, motility, hydrogen sulphide production etc.) as demonstrated by Cheesbrough (2006).

Antimicrobial Susceptibility testing of the Isolates

\section{Preparation of Inoculum}

A single isolated colony was picked using sterile wiréampylobacter jejuni was detected more in loop and carefully streaked on the surface of sterileamples from Ungogo, Kumbotso and Fagge, nutrient agar plate to give well distinct isolatedvile least frequency of occurrence occurred in colonies after incubation at $37^{\circ} \mathrm{C}$ for 18 Tarauni. Salmonella Typhi was detected in high (Cheesbrough, 2002).

Standardization of the inoculum

frequencies in samples collected from Fagge,

Dala, Kumbotso and Ungogo, while the positive Well isolated colonies from each overnight culture ofontrol has I zero frequency of occurrence the isolates on nutrient agar were asepticall(Table 2).

transferred into a $5 \mathrm{ml}$ sterile physiological salineCampylobacter jejuni was sensitive to only shake vigorously and its turbidity compared to 0. Gentamicin, Salmonella Typhi was only sensitive McFarland Standard (approximately $1.5 \times 10^{8} \mathrm{cfu} / \mathrm{ml}$ )to ciprofloxacin, while the two bacteria were This was done for each of the test bacterial isolateresistant to other antibiotics tested against them The standardized inocula were used for thetable 3 and 4). Bla-TEM gene was detected in antibacterial susceptibility testing (Cheesbrough60\% of $S$. Typhi and $40 \%$ in Campylobacter 2002).

Table 1: Mean Aerobic Mesophilic Bacterial Counts of ready to eat vegetable Salads hawked in Kano Metropolis

\begin{tabular}{llll}
\hline $\mathrm{S} / \mathrm{N}$ & Sampling sites & AMBC $\left(\mathrm{cfu} / \mathrm{g} \times 10^{5}\right)$ & ICMSF FAO \\
\hline 1 & FAG & $1.37 \pm 0.99^{\mathrm{aj}}$ & $10^{3}$ \\
2 & GWL & $1.40 \pm 1.63^{\mathrm{bj}}$ & \\
3 & TRN & $1.36 \pm 1.36^{\mathrm{cj}}$ & \\
4 & KMC & $1.20 \pm 1.06^{\mathrm{dj}}$ & \\
5 & DAL & $1.70 \pm 1.27^{\mathrm{ej}}$ & \\
6 & KBT & $1.50 \pm 1.49^{\mathrm{fj}}$ & \\
7 & NSR & $1.84 \pm 0.89^{\mathrm{gj}}$ & \\
8 & UGG & $1.23 \pm 2.11^{\mathrm{hj}}$ & \\
9 & Control (Partially Treated) & $0.84 \pm 0.20^{\mathrm{i}}$ & \\
10 & Control (Treated) & $0.00016 \pm 0.00^{\mathrm{ji}}$ & \\
\hline
\end{tabular}

Footnote: Values are mean \pm SD of triplicate data, Values with the same alphabet along the column are considered significant. Key: AMBC - Aerobic Mesophilic Bacterial Count, cfu/g - Coliform Forming Unit/ Gram, FAG - Fagge, GWL - Gwale, TRN Tarauni, KMC - Kano Munincipal, DAL - Dala, KBT - Kumbotso, NSR - Nassarawa, UGG - Ungogo 
BAJOPAS Volume 12 Number 2, December, 2019

Table 2. Frequency of occurrence of isolates sourced from ready-to-eat vegetable salad hawked in Kano metropolis

\begin{tabular}{|c|c|c|c|c|c|c|}
\hline $\mathrm{S} / \mathrm{N}$ & Sampling sites & $\begin{array}{l}\text { Samples } \\
\text { collected }\end{array}$ & C. jejuni & $\begin{array}{l}\text { Percentage } \\
\text { occurrence } \\
(\%)\end{array}$ & S. Typhi & $\begin{array}{l}\text { Percentage } \\
\text { occurrence } \\
(\%)\end{array}$ \\
\hline 1 & FAG & 25 & 5 & 25 & 15 & 75 \\
\hline 2 & GWL & 25 & 4 & 20 & 10 & 50 \\
\hline 3 & TRN & 25 & 2 & 10 & 9 & 45 \\
\hline 4 & $\mathrm{KMC}$ & 25 & 4 & 20 & 11 & 55 \\
\hline 5 & DAL & 25 & 3 & 15 & 14 & 70 \\
\hline 6 & KBT & 25 & 6 & 30 & 12 & 60 \\
\hline 7 & NSR & 25 & 5 & 25 & 10 & 50 \\
\hline 8 & UGG & 25 & 7 & 35 & 12 & 60 \\
\hline 9 & $\begin{array}{l}\text { Control (Part. } \\
\text { Treated) }\end{array}$ & 25 & 0 & 0 & 3 & 15 \\
\hline \multirow[t]{2}{*}{10} & $\begin{array}{l}\text { Control } \\
\text { (Treated) }\end{array}$ & 25 & 0 & 0 & 0 & 0 \\
\hline & Total & 250 & 36 & & 97 & \\
\hline
\end{tabular}

Table 3.Mean zone of inhibition of isolates sourced from ready-to-eat vegetable salad

\begin{tabular}{lllll}
\hline S/N & Antibiotics & Disk potency $(\mu \mathrm{g})$ & \multicolumn{2}{c}{ Zone of inhibition $(\mathrm{mm})$} \\
\hline & & & C. jejuni $\mathrm{n}=36$ & S. Typhi $\mathrm{n}=97$ \\
1 & AUG & 30 & 6.0 & 6.0 \\
2 & CXM & 05 & 6.0 & 6.0 \\
3 & GEN & 10 & 20 & 8.0 \\
4 & CRX & 30 & 6.0 & 6.0 \\
5 & CAZ & 30 & 6.0 & 6.0 \\
6 & CPR & 05 & 10 & 20 \\
7 & OFL & 05 & 14 & 15 \\
8 & NIT & 300 & 15 & 9.0 \\
\hline
\end{tabular}

Key: AUG- Augmentin, CAZ- Ceftazidime, CXM- Cefixime, CPR- Ciprofloxacin, GEN- Gentamicin, OFLOfloxacin, CRX- Cefuroxime, NIT- Nitrofurantoin, $6 \mathrm{~mm}$-disk diameter which indicate no activity.

Table 4. Antibiotic Resistance profile of isolates sourced from ready-to-eat vegetable salad hawked in Kano

\begin{tabular}{|c|c|c|c|c|c|}
\hline $\mathrm{S} / \mathrm{N}$ & & Antibiotics & & Resistance profile & \\
\hline & & & & C. jejuni $\mathrm{n}=36$ & S. Typhi $\mathrm{n}=97$ \\
\hline 1 & & AUG & & $\mathrm{R}$ & $\mathrm{R}$ \\
\hline 2 & & CXM & & $\mathrm{R}$ & $\mathrm{R}$ \\
\hline 3 & & GEN & & S & $\mathrm{R}$ \\
\hline 4 & & CRX & & $\mathrm{R}$ & $\mathrm{R}$ \\
\hline 5 & & CAZ & & $\mathrm{R}$ & $\mathrm{R}$ \\
\hline 6 & & CPR & & $\mathrm{R}$ & I \\
\hline 7 & & OFL & & I & I \\
\hline 8 & & NIT & & I & $\mathrm{R}$ \\
\hline Key: & & & & & \\
\hline AUG & $\leq 13 \mathrm{~mm}(\mathrm{R})$ & $14 \mathrm{~mm}(\mathrm{I})$ & $\geq 18 \mathrm{~mm}(\mathrm{~S}$ & & \\
\hline CXM & $\leq 15 \mathrm{~mm}(\mathrm{R})$ & $16 \mathrm{~mm}(\mathrm{I})$ & $\geq 19 \mathrm{~mm}$ (S & & \\
\hline GEN & $\leq 12 \mathrm{~mm}(\mathrm{R})$ & $13 \mathrm{~mm}(\mathrm{I})$ & $\geq 15 \mathrm{~mm}$ (S & & \\
\hline CRX & $\leq 14 \mathrm{~mm}(\mathrm{R})$ & $15 \mathrm{~mm}(\mathrm{I})$ & $\geq 18 \mathrm{~mm}$ (S & & \\
\hline CAZ & $\leq 14 \mathrm{~mm}(\mathrm{R})$ & $15 \mathrm{~mm}(\mathrm{I})$ & $\geq 18 \mathrm{~mm}$ (S & & \\
\hline CPR & $\leq 15 \mathrm{~mm}(\mathrm{R})$ & $16 \mathrm{~mm}(\mathrm{I})$ & $\geq 21 \mathrm{~mm}$ (S & & \\
\hline OFL & $\leq 12 \mathrm{~mm}(\mathrm{R})$ & $13 \mathrm{~mm}(\mathrm{I})$ & $\geq 16 \mathrm{~mm}$ (S & & \\
\hline NIT & $\leq 14 \mathrm{~mm}(\mathrm{R})$ & $15 \mathrm{~mm}(\mathrm{I})$ & $\geq 17 \mathrm{~mm}$ (S & & \\
\hline $\begin{array}{l}\text { Class } \\
(200\end{array}$ & tion of sensiti & and resista & S. Typhi an & C. jejuni to antib & pted from Cheesbrough \\
\hline
\end{tabular}


BAJOPAS Volume 12 Number 2, December, 2019

Table 5: Percentage Resistance profile of isolates sourced from ready to eat vegetables isolates

\begin{tabular}{lllllll}
\hline S/N & Antibiotics & Resistant (\%) & Susceptible (\%) & Resistant (\%) & Susceptible & $(\%)$ \\
\hline & & \multicolumn{2}{c}{ C. jejuni } & \multicolumn{2}{c}{ S.Typhi } \\
1 & AUG & 100 & 0 & 100 & 0 \\
2 & CXM & 100 & 0 & 100 & 0 \\
3 & GEN & 98.4 & 1.6 & 99.3 & 0.6 \\
4 & CRX & 100 & 0 & 100 & 0 \\
5 & CAZ & 100 & 0 & 100 & 0 \\
6 & CPR & 99.2 & 0.8 & 98.4 & 1.6 \\
7 & OFL & 98.8 & 1.2 & 98.8 & 1.2 \\
8 & NIT & 98.8 & 1.2 & 99.2 & 0.8 \\
\hline
\end{tabular}

Table 6: percentage of occurrence TEM resistance gene on Campylobacter jejuni and Salmonella Typhi isolated from ready to eat vegetable salads

\begin{tabular}{lllll}
\hline S/N & Name of Orgnism & No of sample collected & $\begin{array}{l}\text { No of positive } \\
\text { samples }\end{array}$ & $\begin{array}{l}\text { Percentage of occurrence } \\
(\%)\end{array}$ \\
\hline 1 & $\begin{array}{l}\text { Campylobarterr } \\
\text { jejuni }\end{array}$ & 5 & 2 & 40 \\
2 & Salmonella Typhi & 5 & 3 & 60 \\
\hline
\end{tabular}

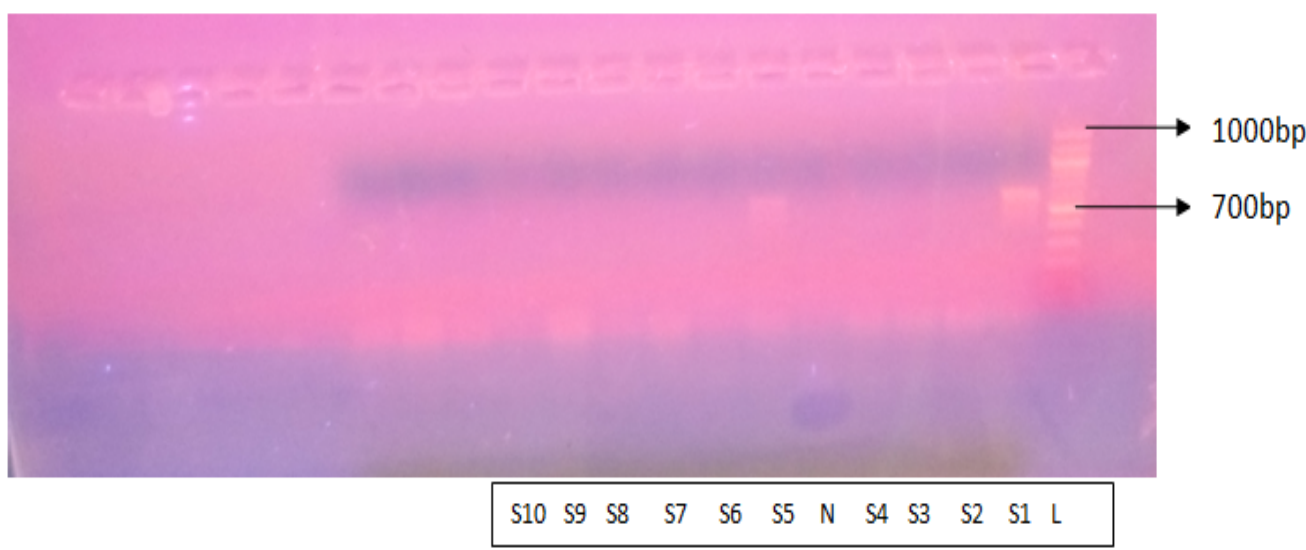

Plate I: Gel picture of TEM gene detection on Campylobacter jejuni and Salmonella Typhi

KEY:

$L$ is 100 bp DNA ladder

$\mathrm{S} 1$ and $\mathrm{S} 6$ are positive for TEM, Product size is $700 \mathrm{bp}$

S2-S4 and $\mathrm{N}$ are Negative for TEM

$\mathrm{N}$ is Negative control

$\mathrm{S}$ stands for sample

$\mathrm{S} 1=\mathrm{Ca} .1$ (from client and so on)

Some positive bands are faint.

\section{DISCUSSION}

The results of the aerobic mesophilic bacterial counts of the ready-to-eat vegetable samples sourced from the eight metropolitant Local Government areas in Kano revealed that the mean counts of all samples were above $1.00 \times 10^{5} \mathrm{cfu} / \mathrm{g}$. These findings were similar to that of Bukar et al. (2010), who recorded aerobic mesophilic count above the maximum acceptable limit set by Food and Agricultural Organization in lettuce, cabbage and tomato $\left(1.40 \times 10^{6}\right.$ to $\left.1.60 \times 10^{7} \mathrm{CFU} / \mathrm{g}\right)$ sourced from Kwakwaci irrigation site, in Fagge LGA of Kano State. Similarly, the findings were similar to that of Gbonjubola et al. (2012) and Chikodili et al, (2015) who recorded high bacterial load ranging from $6.0 \times 10^{4} \mathrm{cfu} / \mathrm{g}$ to $2.0 \times 10^{6} \mathrm{cfu} / \mathrm{g}$ on vegetable salads sourced from restaurants in Zaria, Kaduna State, Nigeria. The high bacterial counts of the samples investigated in this research could be attributed to the usage of animal dungs as fertilizers, cultivation of vegetables with sewage polluted water (domestic sewage), contact with soil and dust, poor handling and processing, use of contaminated water during processing, contaminated utensils and usage of bare hands during servicing of the product to the end users. 
BAJOPAS Volume 12 Number 2, December, 2019

The aerobic mesophilic bacterial counts of all the samples were found to be above the maximum acceptable counts of $10^{3} \mathrm{cfu} / \mathrm{g}$ as reported by International Commission on Microbiological Specification for Foods. In view of this, the ready-to-eat vegetable salads sold in the sampling sites can be reported as unsafe for human consumption.

The mean aerobic mesophilic count of control (partially treated) was found to be $8.41 \times 10^{4}$ $\mathrm{cfu} / \mathrm{g}$, while control (treated), the AMBC dropped to $1.6 \times 10^{2} \mathrm{cfu} / \mathrm{g}$ which was within the acceptable limit and were safe for consumption.

The presence of these bacteria (Campylobacter jejuni and Salmonella Typhi) in the ready-to-eat vegetable salads could be attributed to poor cultivation practices, bad handling and transportation practices, poor personal and environmental hygiene during processing and selling of the vegetable salads.

Campylobacter jejuni shows high resistance to most of the assayed antibiotics, while very low resistance to gentamicin was observed. Similarly, Salmonella Typhi demonstrated very high resistance to most antibiotics used in the study. This observed resistance to the antibiotics is an indication of earlier exposure of the isolates to these drugs or the acquisition of the genes from other bacteria through processes such as conjugation, transduction or transformation.

Resistance of food borne pathogens including Campylobacter jejuni and Salmonella Typhi to multiple antibiotics is becoming an emerging public health issue worldwide. In addition, the use of antibiotics in agricultural practices may have contributed immensely to the development resistant food borne pathogens. This can lead to some bacteria developing resistance against the antibiotics being used to control them. Subsequently, humans and animals share these pathogens which find their way into water bodies some of which are used to irrigate vegetables. The result of this is that vegetables get contaminated with these resistant pathogens which can also be easily transferred to other food sources. Sources including application of manures to the farm from slaughter houses, in vitro propagation of crops (tissue cultured plants), antibiotics spray on the crops in the orchard, soil and water contamination with faecal material and effluent from farm animals at the field, and genetic engineering causing increased antibiotic resistance have been noted as sources by which antibiotic resistance are incorporated into fruits and vegetables.

The antimicrobial resistance profile of the isolated Campylobacter jejuni revealed a high percentage of the organisms showing multiple drug resistance to commonly used antibiotics. Infections with antibiotic resistant bacteria make the therapeutic options for infections treatment extremely difficult or virtually impossible in some instances.

This study further shows that TEM resistance gene was detected in both Campylobacter jejuni and Salmonella Typhi isolates. The antimicrobial resistance gene in microflora, food spoilage or opportunistic pathogenic strains contaminating ready to eat vegetable salads form an indirect risk to public health as they increase the gene pool from which pathogenic bacteria can pick up traits. The observation of resistance to multiple antibiotics by the organisms isolated from ready to eat vegetable salads in this study suggest a substantial chance for transfer of antimicrobial resistance to humans because the eventually resistant bacteria are not killed as they are often consumed without cooking or pre-heating, as a consequence, transfer of antimicrobial resistance genes between bacteria after ingestion may occur.

\section{CONCLUSION AND RECOMMENDATION}

In conclusion, the results of this study on ready to eat vegetable salads collected from eight Local Governments of Kano State clearly revealed high bacterial contamination above the acceptable limit. The ready to eat vegetable salads were contaminated with Campylobacter jejuni having 36(18\%) and Salmonella Typhi having $97(48.5 \%)$ rates of occurrence. Over $90 \%$ of the isolates were resistant to tested antibiotics and as such pose substantial risk for transfer of antimicrobial resistance to humans as they are consumed without having undergone prior preservation or additional processing.TEM resistance gene was detected in Campylobacter jejuni with 2(40\%) and Salmonella Typhi with $3(60 \%)$. It is recommended that vegetable salad hawkers should be enlighted on hygienic vegetable salad processing and handling methods as well as the public health importance of campylobacteriosis and salmonellosis thereby ensuring food safety. Washing of vegetable salads with just water is inadequate to remove all contaminating pathogens. Therefore, the use of distilled white vinegar should be employed in order to reduce the bacterial load.

\section{REFERENCES}

Abdul-Raouf, U.M. and Ammar, M.S. (2011). Survival and growth of Escherichia coli on ready - to - eat salad vegetables. Journal of Applied Environmental Microbiology, Vol. 7(2) pp. $111-114$. 
BAJOPAS Volume 12 Number 2, December, 2019

Adesetan, T. O., Egberongbe, H. O., Ilusanya, O. A. F. and Bello, O.O. (2013). Antimicrobial sensitivity of bacterial isolates from street vended fruits in Ijebu area of Ogun state, Nigeria. International Research Journal of Microbiology. 4(9): 220-225.

Adeshina, G.O., Jibo, S.D and Agu, V.E. (2012). Antibacterial Susceptibility Pattern of Pathogenic Bacteria Isolates from Vegetable Salad Sold in Restaurants in Zaria, Nigerian Journal of Microbiology, 2:5-11.

Beuchat, L.R. and Ryu, J. (1997). Produce handling and processing practices. Emerging Infectious Disease. 3, 1-9.

Bukar, A., Uba, A., and Oyeyi, T.I. (2010). Occurrence of some entropathogenic Bacteria in some Minimally and fully processed ready to eat food in Kano Metropolis Nigeria. African Journal of Food Science, vol. 4(2). Pp $32-36$.

Chai, L.C., Fatimah, A.B., Ghazali, F.M., Lee, H.Y., Tunung, R., Shamsinar, A.T., Laila R.A. S., Thahirahtul, A. Z., Malakar, P. M., Nakaguchi, Y., Nishibuchi, M. and Son, R. (2008). Biosafety of Campylobacter jejuni from Raw Vegetables Consumed as Ulam with Reference to their Resistance to Antibiotics, International Food Research Journals, 15(2), 125-134.

Cheesbrough, M. (2002). District Laboratory Practice in Tropical African Countries, part 2 London: Press Sunicate of the University of Cambridge, Pp. $157-234$.

Chikodili, G., Anaukwu, G., Onyinyechukwu, U., Ikechukwu, A.E., Onyedika, C.O., and Kingsley, C.A. (2015). Preliminary Study of Bacterial Isolates from Indigenous Ready To - Eat Salad Vegetables, American Journal of Life Science. Vol. 3, Issue 4, 282-286,

Egboh, S.H.O. and Emeshili, E.M. (2007). Physicochemical Characteristics of River Ethiopesource in Umuaja Delta State, Nigeria. Journal for Chemical Society of Nigeria. 32(2): 72 - 76.

Elexson, N., Nik Yuhanis, F.N. Malcolm, T.T.H., New, C.Y., Chang, W.S. Ubong, A., Kuan, C.H., Loo, Y.Y., Thung, T.Y. and Son, R. (2017). Occurrence of Escherichia coli harbouring stx genes in popiah, $A$ Malaysia street food Research 1(1): 29 - 32.

Gbonjubola, O. Adeshina, Samuel D. Jibo and Victor E. Agu, (2012), Antibacterial Susceptibility Pattern of Pathogenic Bacteria Isolates from Vegetable Salad Sold in Restaurants in Zaria, Nigeria. Journal of Microbiology Research, 2(2): 5-11.

Hassan, A., Utku, O. and Koray, K. (2006). Determination of total aerobic and indicator bacteria on some raw eaten vegetables from wholesalers in Ankara, Turkey. International Journal of Hygiene and Environmental Health 209, 197-201.

Holvoet, K., Sampers I., Callens B., Dewulf, J. and Uyttendaelea M. (2013). Moderate prevalence of antimicrobial resistance in Escherichia coli isolates from lettuce, irrigation water, and soil. Applied and Environmental Microbiology. 79(21): 66776683.

Itohan, A.M, Peters O, Kolo I. (2011). Bacterial contaminants of salad vegetables in Abuja Municipal Area Council, Nigeria. Malaysian Journal Microbiology 7:111-114.

Jong, L.Y. (2010). Detection of Camphylobacter sp. And Campylobacter jejuni in raw vegetables by using Direct polymerase chain reaction. A Thesis submitted in Partial fulfilment of the requirement for the Degree of Bachelor of Science with Honours (Resource Biotechnology), Faculty of Resource Science and Technology Universiti Malaysia Sarawak. Pp. 1 - 133.

Komolafe, O. O. (2003). Antibiotic Resistance in Bacteria-an Emerging Public Health Problem. Malawi Med. J.15 (2):163-69.

New, C.Y., Wong, C.Y., Usha, M., Ubong, A., Nakaguchi, Y., Nishibuchi, M. and Son, R. (2017). Level of Campylobacter jejuni from naturally contaminated chicken liver and chicken legs in various task: a cross contamination study. Food Research 1(2): $33-37$.

Puspanadan, S., Afsah-Hejri, L., Loo, Y., Nillian, E., Kuan, C., Goh, S., Chang, W., Lye, Y., John, Y., Rukayadi, Y., Yoshitsugu, N., Nishibuchi, M., and Son, R. (2012). Detection of Klebsiella pneumoniae in raw vegetables using Most Probable NumberPolymerase Chain Reaction (MPN-PCR). International Food Research Journal, 19, 1757-1762.

Sambrook, J., Fritsch, E.F. and Maniatis, T. (1989), Gel Electrophoresis of DNA. In: Sambrook, J., Fritsch, E.F. and Maniatis, T., Eds., Molecular Cloning: $A$ Laboratory Manual, Chapter 6, Cold Spring Harbor Laboratory Press, Cold Spring Harbor, New York.

Udo, S, Andy, I., Umo, A., and Ekpo, M. (2008). Potential Human Pathogens (bacteria) and their antibiogram in ready-to-eat Salads sold in Calabar, South - South, Nigeria. The International Journal of Tropical Medicine. Volume 5 Number (2). 